CONE-960421--8

UCRL-JC-122572

PREPRINT

\title{
Pitting Corrosion of Container Materials in Anticipated
} Repository Environments ri.

FEg 20 14.

Ajit K. Roy

R. Daniel MoCright

OSTI

This paper was prepared for submittal to the 1996 International High Level Radioactive Waste Management Conference

Las Vegas, NV

April 29 - May 3, 1996

November 22, 1995

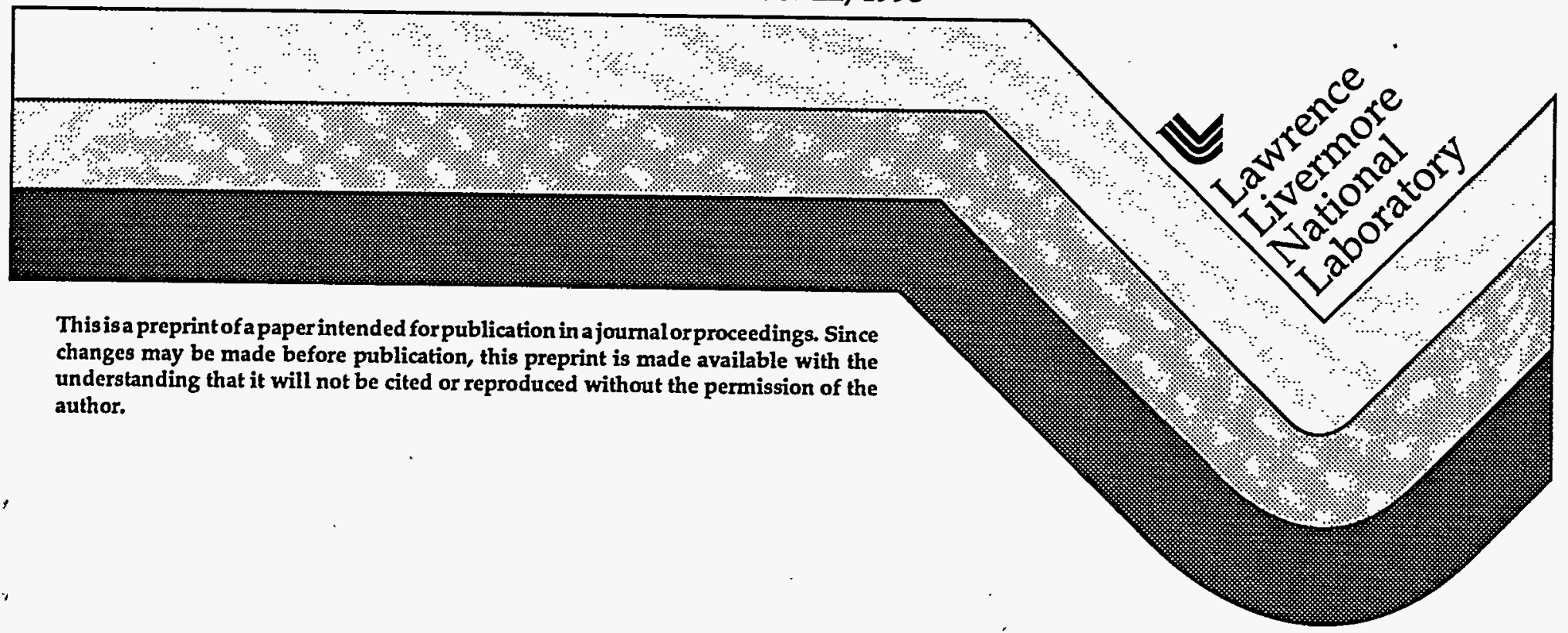




\section{DISCLAIMER}

This document was prepared as an account of work sponsored by an agency of the United States Government. Neither the United States Government nor the University of California nor any of their employees, makes any warranty, express or implied, or assumes anylegal liability or responsibility for the accuracy, completeness, or usefulness of any information, apparatus, product, or process disdosed, or represents that its use would not infringe privately owned rights. Reference herein to any specificcommercial products, process, or service by trade name, trademark, manufacturer, or otherwise, does not necessarily constitute or imply its endorsement, recommendation, or favoring by the United States Government or the University of Colifornia. The views and opinions of authors expressed herein do not necessarily state or reflect those of the United States Government or the University of Califomia, and shall not be used for advertising or product endorsement purposes. 


\section{PITTING CORROSION OF CONTAINER MATERIALS IN ANTICIPATED REPOSITORY ENVIRONMENTS \\ Ajit K. Roy \\ Framatome Cogema Fuels \\ and \\ R. Daniel McCright \\ Lawrence Livermore National Laboratory}

\section{INTRODUCTION}

Multi-barrier waste package design concepts consisting of an outer corrosion-allowance metallic barrier over the corrosion-resistant metallic inner container are currently being considered to accommodate the nation's spent nuclear fuel and vitrified high-level nuclear waste for geologic disposal. Although the ground water in the proximity of the potential repository site is believed to be non-aggressive, under some operating conditions, the repository environments surrounding these waste packages can become very hostile. Under these conditions, the corrosion-resistant metallic container may become susceptible to localized corrosion, such as, pitting. This paper presents the results of pitting corrosion studies of candidate container materials in three different aqueous environments incorporating an electrochemical test technique.

\section{WORK DESCRIPTION}

Materials tested include austenitic Types 304 and 316L stainless steels, nickel-rich Alloys 825 and G-3, nickel-base Alloys C-4 and C-22, titanium-base Ti Gr-12, nickel-copper Alloy 400, and 70/30 Cupronickel. Tests were performed in deaerated neutral; acidic, and alkaline salt solutions ( 52.6 grams per liter of $\mathrm{NaCl}$ ) at room temperature, $60^{\circ} \mathrm{C}$, and $90^{\circ} \mathrm{C}$. The $\mathrm{pH}$ of these solutions ranged between 6 and 7,2 and 3 , and 10 and 11 , respectively.

A three-electrode technique was used to conduct cyclic potentiodynamic polarization (CPP) experiments using a cylindrical working electrode, two graphite electrodes, and a luggin capillary connected to a reference electrode. While a saturated calomel reference electrode (SCE) was used at room temperature and $60^{\circ} \mathrm{C}$, a $\mathrm{Ag} / \mathrm{AgCl}$ electrode was used at $90^{\circ} \mathrm{C}$ as a reference electrode. Potential was applied to the 
specimen at the ASTM-specified ${ }^{(\mathrm{I})}$ rate of $0.17 \mathrm{mV} / \mathrm{sec}$ using a potentiostat which was controlled by a PC with corrosion software. A controlled temperature water bath maintained test temperature at the desired value within $\pm 0.1^{\circ} \mathrm{C}$.

Initially the specimen was allowed to reach its stable corrosion potential $\left(E_{c o r}\right)$, followed by an anodic potential scan. The changes in current were automatically recorded, and the resulting polarization curve was displayed on the computer monitor. After polarization to $+200 \mathrm{mV}$ (versus $\mathrm{SCE}$ or $\mathrm{Ag} / \mathrm{AgCl}$ ), the direction of scanning was reversed at the same rate to $\mathrm{E}_{\mathrm{cor}}$, and the CPP plot was printed. The $\mathrm{pH}$ of the solution was measured before and after the test. The tested specimen was cleaned, followed by visual and microscopic evaluations.

\section{RESULTS AND DISCUSSION}

Results indicate that of all the materials tested, Alloy C-4, Alloy C-22, and Ti Gr-12 demonstrated the maximum corrosion resistance, showing no pitting or dissolution in any environment. However, Alloys 825 and G-3 suffered from pitting in acidic concentrated brine at $90^{\circ} \mathrm{C}$. Both Types 304 and $316 \mathrm{~L}$ stainless steels showed severe pitting tendency in all three environments at $60^{\circ} \mathrm{C}$ and $90^{\circ} \mathrm{C}$. Furthermore, Alloy 400 and 70/30 Cupronickel were readily susceptible to dissolution under all environmental conditions. Vigorous reactions occurred in tests involving austenitic stainless steels, Alloy 400 , and 70/30 Cupronickel, resulting in thick dissolution products. Figure 1 shows a macroscopic view of all specimens tested in acidic brine at $90^{\circ} \mathrm{C}$.

In electrochemical terms, the initiation of pitting occurs at a critical potential, $E_{\text {pit, }}$ at which the anodic polarization curve changes its slope showing increase in current density. For susceptible alloys, a hysteresis is observed as the direction of scanning is reversed after some degree of polarization above $\mathrm{E}_{\text {pit }}$ The crossover at the passive current density defines a repassivation or protection potential, $\mathrm{E}_{\text {prot, }}$ below which established pits cannot grow. By contrast, only new pits can initiate at potentials above $\mathrm{E}_{\mathrm{pit}}$. Examination of the CPP diagrams obtained in this investigation indicates that both $\mathrm{E}_{\mathrm{pit}}$ and $\mathrm{E}_{\text {prot }}$ were 
observed for Alloy 825 in acidic solution at $90^{\circ} \mathrm{C}$. For the austenitic stainless steels, $\mathrm{E}_{\mathrm{pit}}$ was identified, but neither material exhibited repassivation behavior in any environment. Instead, an active curve was noted past the forward scan curve upon reversal of the potential scan. The CPP curves for Alloys C-4 and C-22, and Ti Gr-12 consistently showed a counter-clockwise path following scan reversal. The maximum current density attained just prior to potential scan reversal was found to be sufficiently high for alloys showing tendencies to pitting and dissolution.

\section{CONCLUSION}

The results from this study indicate that Alloys 825 and G-3 may undergo pitting in an acidic brine at a temperature near boiling. The fact that Alloy G-3 suffered from pitting despite its higher molybdenum content suggests that another higher grade of nickel-rich material such as Alloy G-30 be evaluated for its pitting corrosion resistance in a similar environment using the CPP technique. Furthermore, potentiostatic experiments are recommended to study pit growth in susceptible environments at controlled electrochemical potentials.

\section{ACKNOWLEDGMENTS}

This work was supported by the U.S. Department of Energy, Office of Civilian Radioactive Waste Management, Yucca Mountain Site Characterization Office, Las Vegas, NV, and performed under the auspices of the U.S. Department of Energy by the Lawrence Livermore National Laboratory under contract number W-7405-ENG-48 and by TRW Environmental Safety Systems Inc. under contract number DE-AC01-RW00134. Assistance of Steve Gordon in performing the experimental work is also thankfully acknowledged.

\section{REFERENCE}

1. "Standard Reference Test Method for Making Potentiostatic and Potentiodynamic Anodic Polarization Measurements," ASTM Designation: G 5-87 
つ.06 fe วu!̣g pajeג\}uasuo pa!j!p!

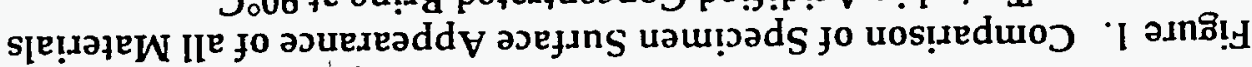

SLL VAJ

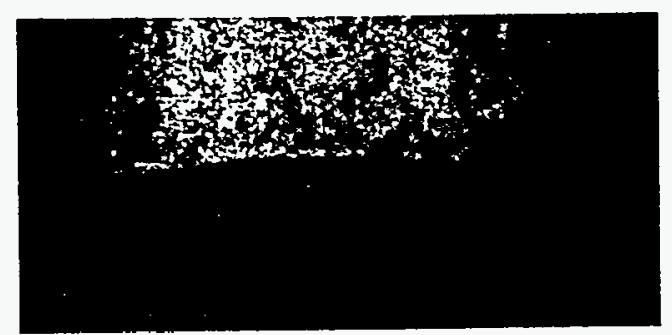

- . 2 00t KolIV
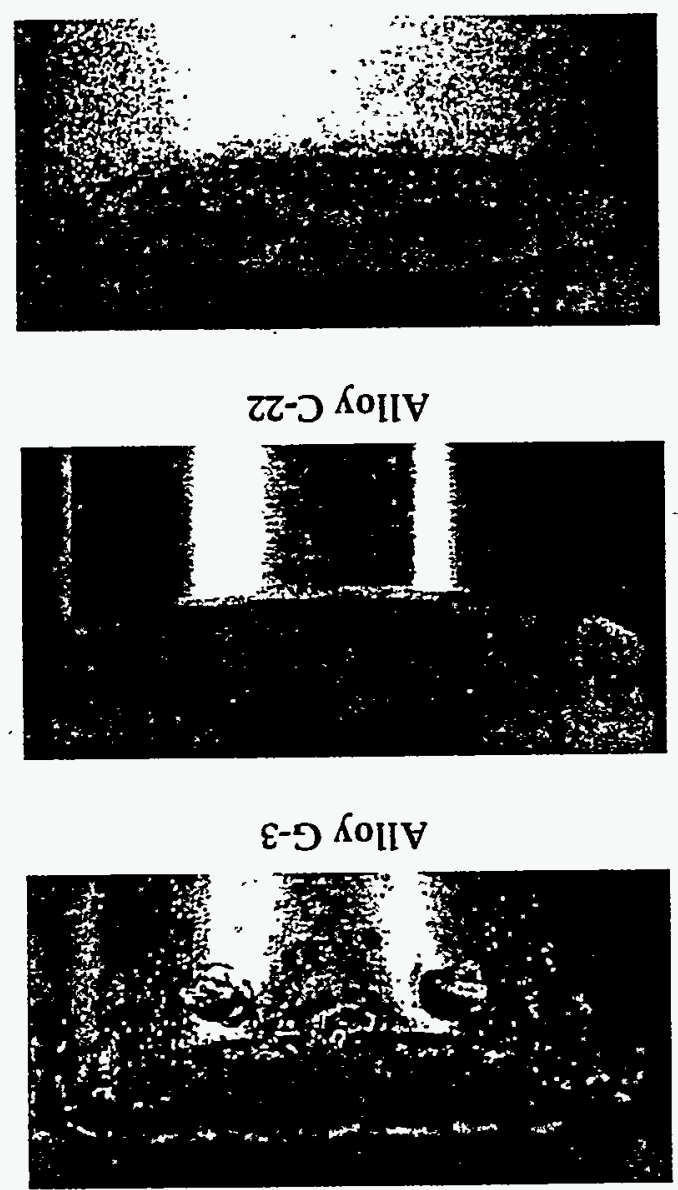

SS T9LE $\partial \mathrm{d} K_{\mathrm{L}}$

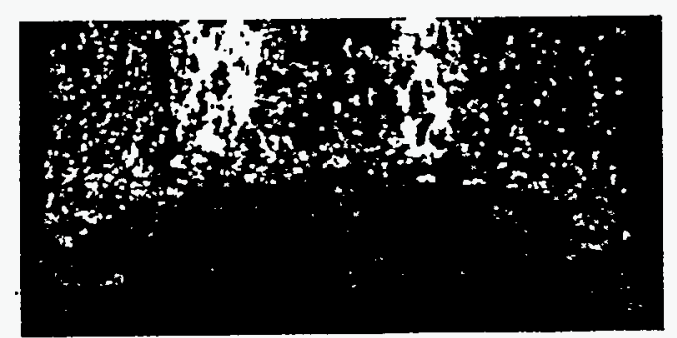

ZI-1S!L
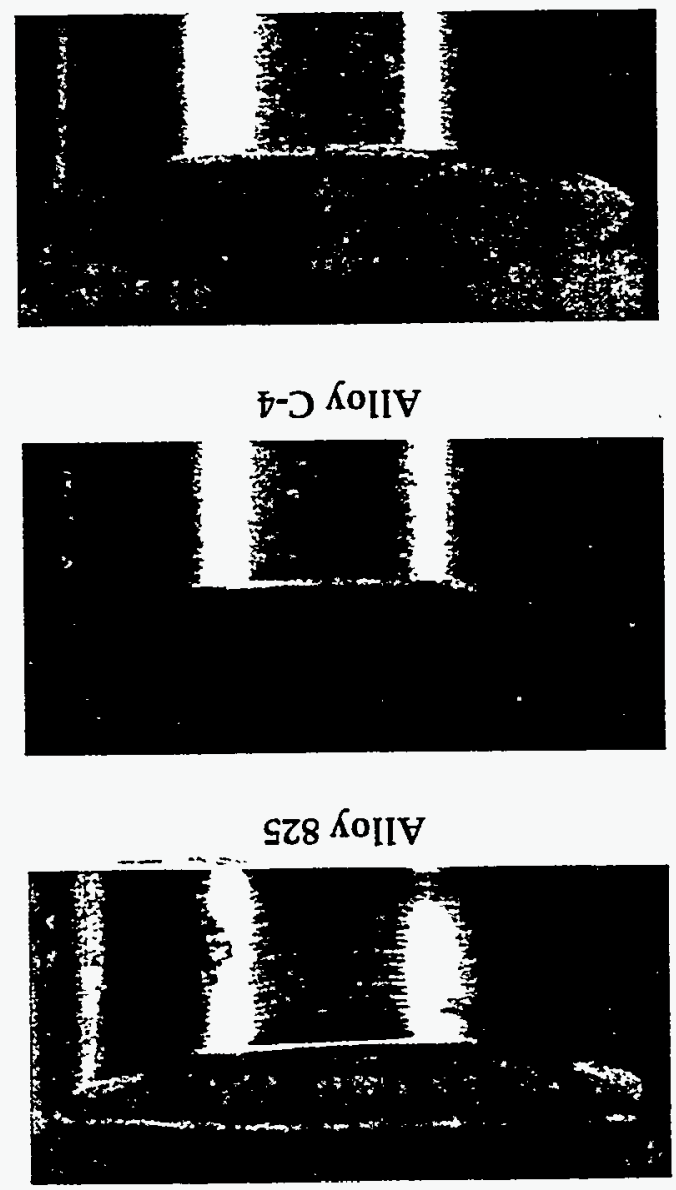

SS $70 \mathcal{E} \partial \mathrm{d} \kappa_{\mathrm{I}}$

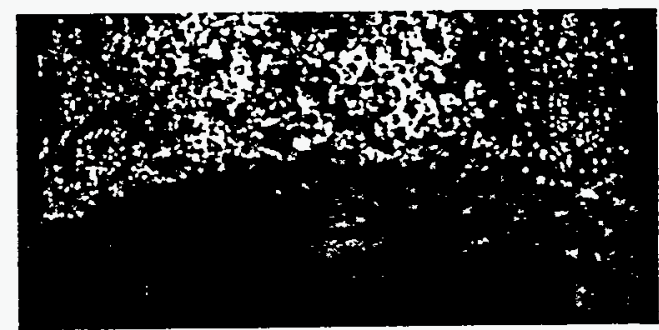





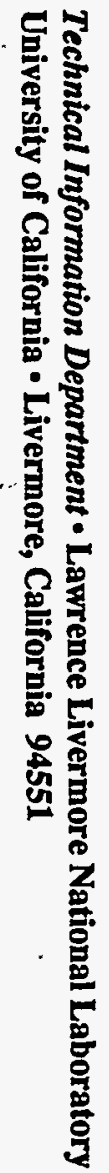

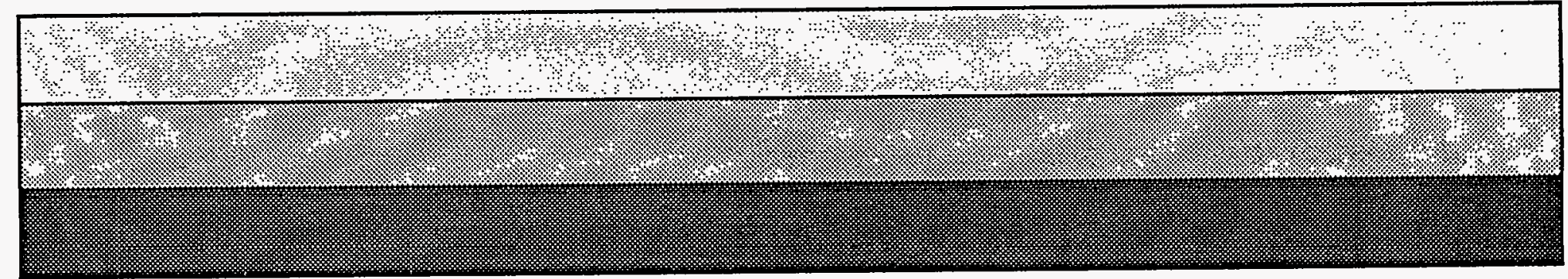

